\title{
Employing End-Functional Polythiophene to Control the Morphology of Nanocrystal-Polymer Composites in Hybrid Solar Cells
}

\author{
Jinsong Liu, Toru Tanaka, Kevin Sivula, A. Paul Alivisatos, and Jean M. J. Fréchet* \\ Contribution from the Department of Chemistry, University of California, Berkeley \\ 94720-1460, and Material Science Division, Lawrence Berkeley National Laboratory, \\ Berkeley, CA 94720 (USA)
}

\section{Supporting Information}

General. THF and toluene were dried over $\mathrm{Na} /$ benzoquinone and freshly distilled before use. Diisopropylamine was distilled over $\mathrm{CaH}_{2}$ before use. DMF was anhydrous and reagent grade. n-Butyllithium, anhydrous $\mathrm{ZnCl}_{2}, \mathrm{Ni}(\mathrm{dppp}) \mathrm{Cl}_{2}, \mathrm{Pd}\left(\mathrm{PPh}_{3}\right)_{4}$, 2-cyanothiophene, and trimethyltin chloride were purchased from Aldrich and used as received. All reactions were performed under nitrogen atmosphere. The molecular weight of 1 was determined by SEC (polystyrene standards) in toluene at a flow rate of 1 $\mathrm{mL} / \mathrm{min}$ using a Waters 996 PDA detector module equipped with two $8.0 \times 300 \mathrm{~mm}$ mixed-bed SDV, $5 \mu \mathrm{m}$ particle size columns (PSS, Germany) thermostated at $35{ }^{\circ} \mathrm{C}$. Matrix-assisted laser desorption ionization time-of-flight (MALDI-TOF) mass spectrometry was performed on a Perseptive Biosystems Voyager-DE spectrometer using delayed extraction mode and with an acceleration voltage of $20 \mathrm{keV}$. MALDI TOF samples were prepared from THF solutions using terthiophene as the matrix.

P3HT with a Bromine end group (1): A slight variation of a published procedure ${ }^{1}$ was used. To a $100 \mathrm{ml}$ three-necked flask was added THF $(60 \mathrm{ml})$ and diisopropylamine $(3.1 \mathrm{ml}, 22 \mathrm{mmol})$. The mixture was cooled to $-70{ }^{\circ} \mathrm{C}$, and $\mathrm{n}$ butyllithium ( $2.5 \mathrm{M}$ in hexane, $8 \mathrm{ml}, 20 \mathrm{mmol}$ ) was added. The mixture was warmed to room temperature for $5 \mathrm{~min}$ and then cooled to $-78{ }^{\circ} \mathrm{C}$. This freshly generated LDA was transferred via cannula to a solution of 2-bromo-3-hexylthiophene $(5.3 \mathrm{~g}, 21.5 \mathrm{mmol})$ in THF $(160 \mathrm{ml})$ at $-78{ }^{\circ} \mathrm{C}$, and the reaction mixture was stirred at $-78{ }^{\circ} \mathrm{C}$ for $1 \mathrm{~h}$. Anhydrous $\mathrm{ZnCl}_{2}$ beads ( $3.0 \mathrm{~g}, 22 \mathrm{mmol}$ ) were added and the mixture was stirred at -78 
${ }^{\circ} \mathrm{C}$ for about $30 \mathrm{~min}$ until the zinc chloride was completely dissolved. The cooling bath was taken away, and the reaction mixture was warmed to room temperature. $\mathrm{Ni}(\mathrm{dppp}) \mathrm{Cl}_{2}$ (110 mg, $0.21 \mathrm{mmol}$ ) was added and the mixture was stirred for $15 \mathrm{~min}$. The mixture was poured into methanol $(400 \mathrm{ml})$ to precipitate the polymer product. The crude polymer was purified by Soxhlet extraction with methanol $(150 \mathrm{ml})$ and THF $(150 \mathrm{ml})$. The THF fraction was poured into methanol and pure polymer product (1.2 g, 36\% yield) was obtained as purple solid. GPC Polystyrene standards) $: \mathrm{M}_{\mathrm{n}}=7,600$, PDI $=1.3$. MALDI MS (Figure 2-top) of the product indicates that the polymer chains of 1 were terminated with a bromine and a hydrogen $(\mathrm{H} / \mathrm{Br})$. For example, the peak of 3404.61 Daltons matches with 3406.30, which is the calculated mass of polymer $\mathbf{1}$ for DP $=20$.

2-Cyano-5-trimethyltinthiophene (2): To a $250 \mathrm{ml}$ three-neck flask was added THF $(60 \mathrm{ml})$ and diisopropylamine $(3.0 \mathrm{ml}, 21 \mathrm{mmol})$. The mixture was cooled to -70 ${ }^{\circ} \mathrm{C}$, and n-butyllithium $(2.5 \mathrm{M}$ in hexane, $8 \mathrm{ml}, 20 \mathrm{mmol})$ was added. The mixture was warmed to room temperature for $5 \mathrm{~min}$ and then cooled to $-78{ }^{\circ} \mathrm{C}$. To this freshly generated LDA was added 2-cyanothiophene $(2.18 \mathrm{~g}, 20 \mathrm{mmol})$ via syringe at a period of $2 \mathrm{~min}$. The mixture was stirred at $-70{ }^{\circ} \mathrm{C}$ for $1 \mathrm{~h}$ and trimethyltin chloride $(1.0 \mathrm{M}$ in THF, $20 \mathrm{ml}, 20 \mathrm{mmol}$ ) was added via syringe in a period of $5 \mathrm{~min}$. The reaction mixture was stirred at $-70{ }^{\circ} \mathrm{C}$ for $30 \mathrm{~min}$ and then at room temperature overnight. The mixture was partitioned between water and ether and the organic layer was washed with brine and dried over $\mathrm{Na}_{2} \mathrm{SO}_{4}$. After removal of solvent, the product (3.9 g, 72\%) was obtained by distillation $\left(65^{\circ} \mathrm{C}, 0.05 \mathrm{mmHg}\right)$. Anal. Calcd for $\mathrm{C}_{8} \mathrm{H}_{11} \mathrm{NSSn}$ : C, 35.33; H, 4.08; N, 5.15; S, 11.79; Sn, 43.65. Found: C, 35.30; H, 4.12; N, 5.16; S, 11.78. ${ }^{1} \mathrm{H}$ NMR $\left(\mathrm{CDCl}_{3}\right) \delta$ $7.70(\mathrm{~d}, J=3.6 \mathrm{~Hz}, 1 \mathrm{H}), 7.16(\mathrm{~d}, J=3.6 \mathrm{~Hz}, 1 \mathrm{H}), 0.43(\mathrm{~s}, 9 \mathrm{H})$.

P3HT with a cyano end group (3): To a $100 \mathrm{ml}$ three-necked flask was added 1 $(0.4 \mathrm{mg}, \sim 0.054 \mathrm{mmol})$ and toluene $(40 \mathrm{ml})$. The mixture was stirred at $80{ }^{\circ} \mathrm{C}$ until 1 was completely dissolved. To this polymer solution was added 2 (0.6 g, $2.2 \mathrm{mmol})$, $\mathrm{Pd}\left(\mathrm{PPh}_{3}\right)_{4}(0.13 \mathrm{~g}, 0.11 \mathrm{mmol})$, and $\mathrm{DMF}(8 \mathrm{ml})$. The reaction mixture was heated to 120 ${ }^{\circ} \mathrm{C}$ and stirred at that temperature for $24 \mathrm{~h}$. The mixture was cooled to room temperature and poured into methanol $(200 \mathrm{ml})$ to precipitate the polymer. The crude polymer was purified by Soxhlet extraction with methanol $(150 \mathrm{ml})$ and THF $(150 \mathrm{ml})$. The THF fraction was poured into methanol $(200 \mathrm{ml})$, filtered, and dried to afford a purple product 
(0.37 g, 94\%). ${ }^{1} \mathrm{H}$ NMR $\left(\mathrm{CDCl}_{3}\right)$ (Figure 1-top) of the polymer product exhibits two doublets at $\delta 7.58(J=3.9 \mathrm{~Hz})$ and $\delta 7.11(J=3.9 \mathrm{~Hz})$, which correspond to the two protons of the cyanothiophene ring on the end of the polymer. GPC: $\mathrm{M}_{\mathrm{n}}=7,600, \mathrm{PDI}=$ 1.29. MALDI MS (Figure 2-middle) of the product also reveals the end group transformation. The $\mathrm{H} / \mathrm{Br}$ peaks disappear completely and the new peaks, according to mass calculation, correspond very well to polymer chains with a thienylnitrile moiety. For instance, the peak of 3434.38 Daltons matches well with 3434.54 , which is the calculated mass of polymer 3 provided that the DP $=20$.

P3HT with an amino end (4): To a flame-dried flask was added 3 (0.3 g, 0.04 mmol) and THF (40 ml). The mixture was stirred at $60{ }^{\circ} \mathrm{C}$ until the polymer was completely dissolved. To this polymer solution was added $\mathrm{LiAlH}_{4}(1.0 \mathrm{M}$ in THF, 1.0 $\mathrm{ml}, 1.0 \mathrm{mmol}$ ) and the solution was stirred at reflux overnight. The solution was acidified with aqueous $\mathrm{HCl}(0.5 \mathrm{ml}$ of $2 \mathrm{M}$ solution, $1 \mathrm{ml})$, and was then poured into methanol $(300 \mathrm{ml})$ to precipitate the polymer. The crude polymer was purified by Soxhlet extraction with methanol $(150 \mathrm{ml})$ and THF $(150 \mathrm{ml})$. Triethylamine $(5 \mathrm{ml})$ was added into the THF fraction and the solution was refluxed for $5 \mathrm{~min}$. The THF solution was poured into methanol $(200 \mathrm{ml})$, filtered, and dried to give a purple solid $(0.28 \mathrm{~g}, 93 \%)$. GPC: $\mathrm{M}_{\mathrm{n}}=7,600, \mathrm{PDI}=1.30 .{ }^{1} \mathrm{H} \mathrm{NMR}\left(\mathrm{CDCl}_{3}\right)$ (Figure 1-bottom) of the product exhibits a small singlet peak at $\delta 4.10$, which corresponds to the $-\mathrm{CH}_{2} \mathrm{NH}_{2}$ of 4 . In addition, MALDI-ToF MS (Figure 2-bottom) also confirms the expected end group structure. For example, the peak of 3438.16 Daltons matches well with 3438.57 , which is the calculated mass of polymer $\mathbf{4}$ provided that the $\mathrm{DP}=20$. 

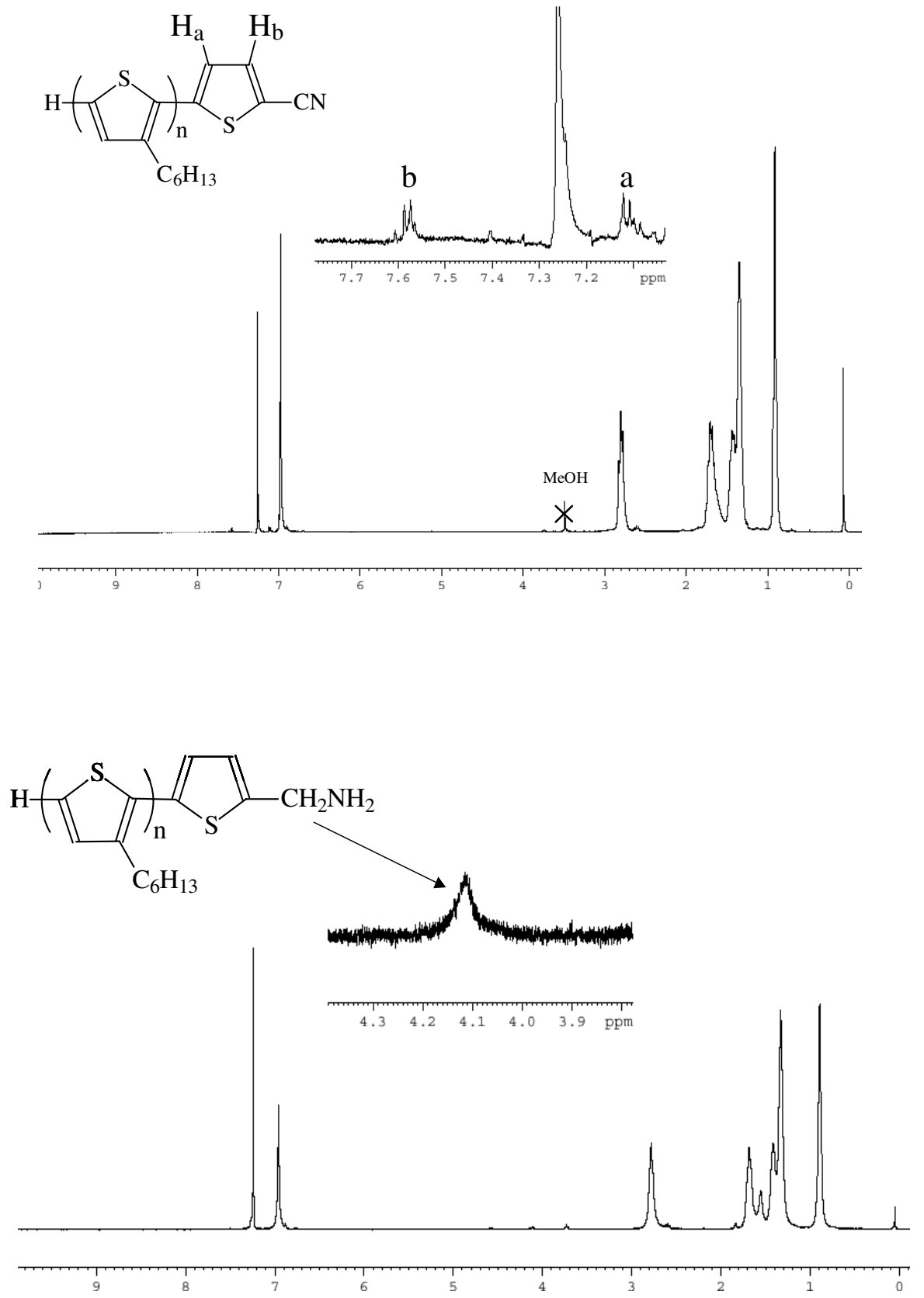

Figure 1. 1H NMR of polymer 3 (top) and polymer 4 (bottom). 

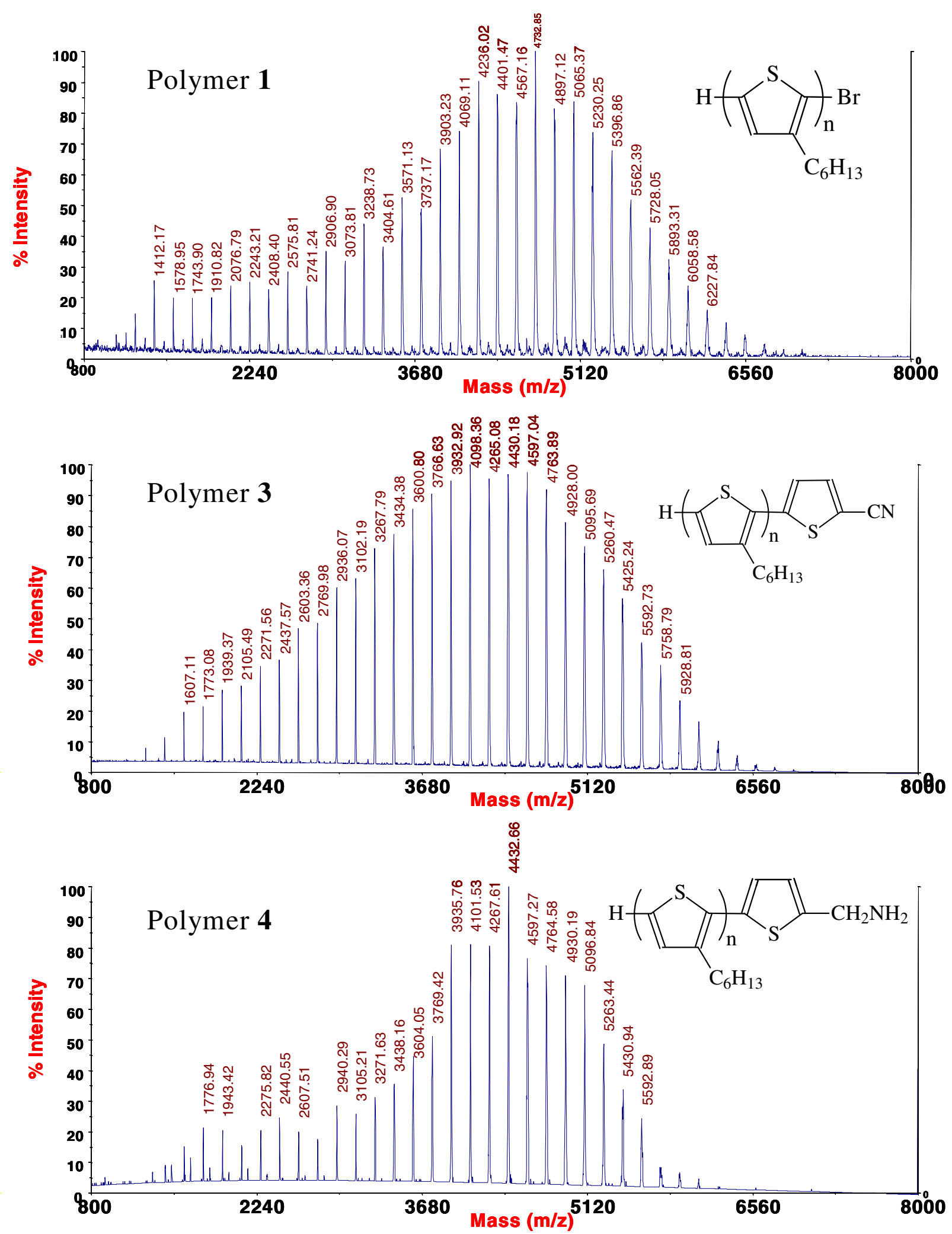

Figure 2. MALDI ToF MS of polymer 1, 3, and $\mathbf{4}$ measured at the same instrumental parameters (laser intensity: 1625; accelerating voltage: $2000 \mathrm{v}$; grid: $94 \%$; guide wire: 0.005; delay time: $100 \mathrm{~ns})$ 
CdSe nanocrystals. $\mathrm{CdO}(0.308 \mathrm{~g}, 2.40 \mathrm{mmol})$, tetradecylphosphonic acid (1.336 $\mathrm{g}, 4.80 \mathrm{mmol}$ ) and trioctylphosphine oxide $(4.36 \mathrm{~g})$ were loaded into the reaction flask and heated up to $100{ }^{\circ} \mathrm{C}$ under argon and degassed for $20 \mathrm{~min}$. The mixture was heated to $300{ }^{\circ} \mathrm{C}$ under argon. After the solution became clear, trioctylphosphine $(2.25 \mathrm{~g})$ was added. The solution was stirred for 5-10 min and selenium solution in trioctylphosphine $\left(15 \mathrm{wt} \%, 1.263 \mathrm{~g}, 2.40 \mathrm{mmol}\right.$ of $\mathrm{Se}$ ) was then injected very quickly at $300{ }^{\circ} \mathrm{C}$. The temperature of the mixture dropped down to $290{ }^{\circ} \mathrm{C}$ and the mixture was kept at $290{ }^{\circ} \mathrm{C}$ for $5 \mathrm{~min}$. The mixture was cooled down quickly by the flow of air to the flask wall. Toluene $(5 \mathrm{ml})$ was added into the flask at around $60{ }^{\circ} \mathrm{C}$, and the mixture was transferred into a vial under argon atmosphere of a glove box. The minimum amount of 2-propanol (about 5-7 ml) was added dropwise to the vial under vigorous stirring, and the mixture was centrifuged for $5 \mathrm{~min}$ immediately after the addition of 2-propanol. The supernatant solution was quickly removed with a pipette. The precipitate was re-dissolved in the minimum amount of toluene (about $1 \mathrm{ml}$ ) and re-precipitated with minimum amount of 2propanol (about 0.5 to $1 \mathrm{ml}$ ). Nanocrystals were obtained as wet precipitates and stored in glove box before use.

Procedure for making cosolutions of nanocrystals and polythiophenes. The whole synthetic batch of CdSe nanocrystals was refluxed in $20 \mathrm{ml}$ of pyridine for 24 hours under argon, and then precipitated with excess hexane, and centrifuged. The supernatant solution was discarded. To remove the salt formed by the pyridine and phosphonic acid, toluene was added to wash the precipitate. The precipitate was recovered by centrifugation, and dispersed into $2.00 \mathrm{ml}$ of pyridine: $\mathrm{CHCl}_{3}$ mixture $(\mathrm{v} / \mathrm{v}$ 1:9). After ultra-sonication for $5 \mathrm{~min}$, the nanocrystal solution was centrifuged at 3300 rpm for 30-60 min with Fisher Centrific* Model 228 Benchtop Centrifuge and then filtered through a membrane filter (Hydrophobic PTFE $0.45 \mu \mathrm{m}$, Millipore Millex-FH). The concentration of the solution was usually between 15 and $20 \mathrm{mg} / \mathrm{ml}$, which was determined based on a weigh of dry residue obtained from a known volume of the solution. This nanocrystal solution was then mixed with the polythiophene solution (15.0 $\mathrm{mg} / \mathrm{ml}$ ) in pyridine: $\mathrm{CHCl}_{3}$ mixture (v/v 1:9) to afford the cosolutions. 
TEM studies. The TEM was performed on thin films using a FEI Tecnai 12 electron microscope operating at $100 \mathrm{kV}$ at the UC Berkeley Electron Microscope Lab. TEM samples were prepared by spin coating from the cosolutions of $\mathrm{CdSe}$ and polymers (7 $\mathrm{mg} / \mathrm{ml}$ ) onto $\mathrm{NaCl}$ substrates. The films were then floated off the $\mathrm{NaCl}$ onto the surface of a water bath, and transferred to holey carbon grids. The film thickness was controlled by changing the spin-coating rate. Both thicker (spun at $1000 \mathrm{rpm}$ ) and thinner (spun at $2000 \mathrm{rpm}$ ) films exhibit better dispersion of nanocrystals in polymer 4 compared to that in polymer 1. Figure 3 below displays the TEM image comparison of the thinner films, while Figure 4 shows the comparison of the thicker film made using polymer 1 and polymer 4 respectively.

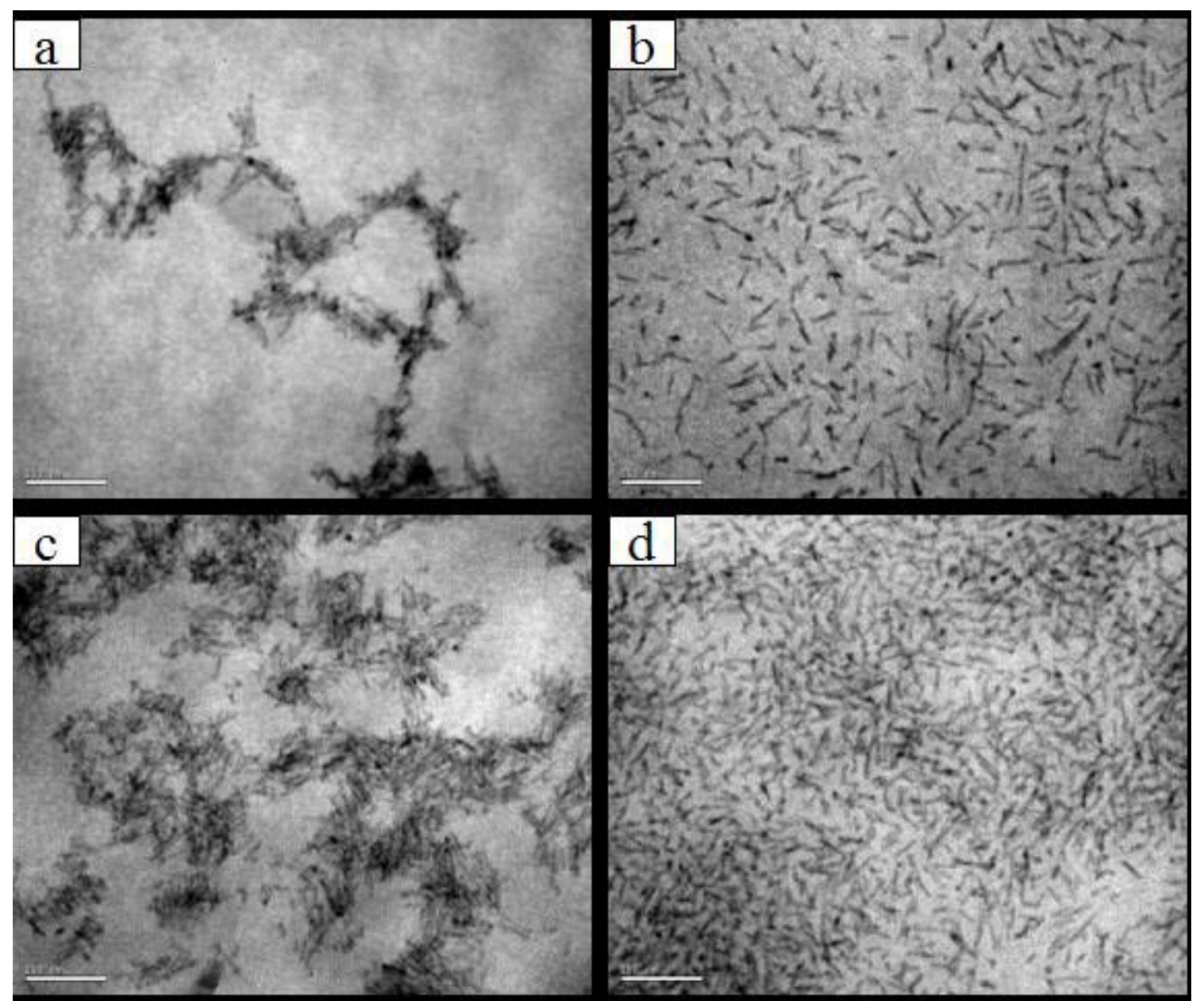

Figure 3. TEM images of thin films consisted of CdSe (5 vol.\%) and polymer 1 (a); CdSe (5 vol.\%) and polymer 4 (b); CdSe (12 vol.\%) and polymer 1 (c); CdSe (12 vol.\%) and polymer 4 (d). The white bar is $100 \mathrm{~nm}$ in all images. 


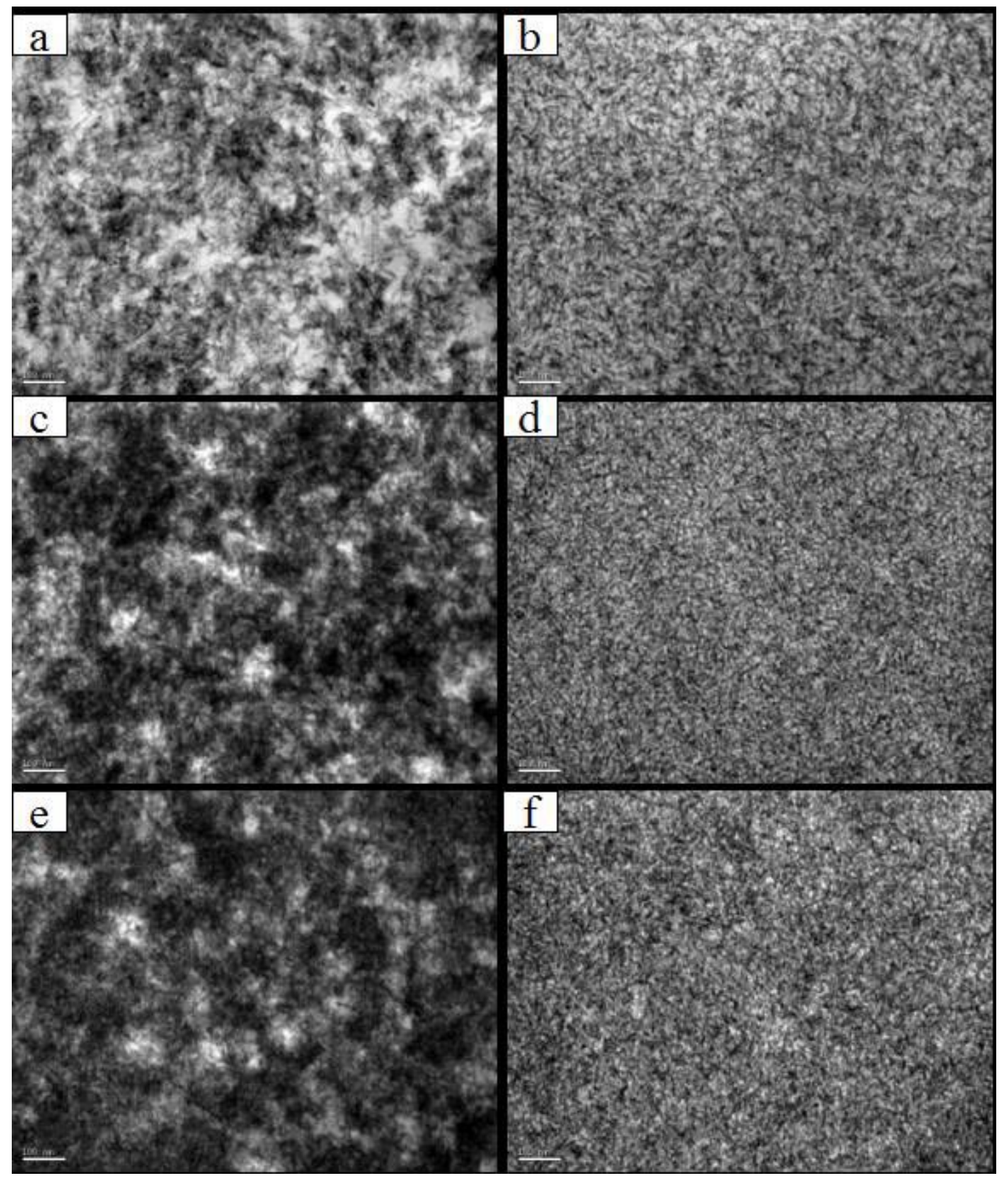

Figure 4. TEM images of thicker films consisting of polymer 1 and CdSe (12 vol.\%) (a); polymer 4 and CdSe (12 vol.\%) (b); polymer 1 and CdSe (26 vol.\%) (c); polymer 4 and CdSe (26 vol.\%) (d); polymer 1 and CdSe (43 vol.\%) (e); polymer 4 and CdSe (43 vol.\%) (f). The white bar is $100 \mathrm{~nm}$ in all images. 
Procedure for making devices. The indium tin oxide (ITO)-coated glass substrates were cleaned by ultrasonication in acetone $(20 \mathrm{~min})$ and soap solution (20 $\mathrm{min}$ ), and rinsed with deionized water, cleaned by ultrasonication in deionized water (20 $\mathrm{min}$ ) and 2-propanol (20 $\mathrm{min}$ ), and dried with nitrogen stream. Finally, the substrates were treated with oxygen plasma for 4 min. A layer of poly $(3,4-$ ethylenedioxythiophene):polystyrene sulfonic acid (PEDOT:PSS) was spun onto the substrate at $3000 \mathrm{rpm}$ for $60 \mathrm{sec}$ and the coated substrate was baked under argon at $125^{\circ} \mathrm{C}$ for 1 hour. The thickness of PEDOT:PSS was determined by AFM to be $60 \mathrm{~nm}$. The cosolution of nanocrystals and polythiophene was spun onto the substrate at $1000 \mathrm{rpm}$ for $60 \mathrm{sec}$ and then annealed at $150^{\circ} \mathrm{C}$ for 1 hour. Aluminum $(100 \mathrm{~nm})$ was evaporated on the active layer at a rate of $0.3-0.5 \mathrm{~nm} / \mathrm{sec}$. The active area of the device was $0.03 \mathrm{~cm}^{2}$.

Measurement of solar cell performance. The current-voltage characteristics of devices were measured using Oriel Solar Simulator and a Keithley 236 Source Measure Unit, connected to the solar cell in a homemade airtight holder. All measurements were performed under A.M 1.5 Global light at an intensity of $100 \mathrm{~mW} \mathrm{~cm}{ }^{-2}$. The absorbance of the solar cell was measured with an Agilent Chemstation UV/Vis Spectrophotometer. Solar power conversion efficiency $\eta$ of a solar cell was calculated according to the following equation:

$$
\eta=\mathrm{J}_{\mathrm{sc}} * \mathrm{~V}_{\mathrm{oc}} * \mathrm{FF} / \mathrm{I}_{\text {light }}
$$

where $J_{\mathrm{sc}}$ is the short-circuit current density in $\mathrm{mA} / \mathrm{cm}^{2}, \mathrm{~V}_{\mathrm{oc}}$ is the open-circuit voltage and $\mathrm{I}_{\text {light }}$ is the intensity of irradiating light in $\mathrm{mW} / \mathrm{cm}^{2}$, and $\mathrm{FF}$ (fill factor) is defined as following:

$$
\mathrm{FF}=\max \{\mathrm{J} * \mathrm{~V}\} / \mathrm{J}_{\mathrm{sc}} * \mathrm{~V}_{\mathrm{oc}}
$$

Figure 5 displays the open circuit voltage of our devices. It indicates that Voc of devices made using polymer $\mathbf{4}$ is proportional to the volume ratio of the polymer in the active composites. However, this tendency was not seen when polymer $\mathbf{1}$ was used.

Figure 6 shows the short-circuit current density of our tested devices. Obviously, the devices made using polymer $\mathbf{4}$ always have higher current density than those made using polymer 1. However, the fill-factors of these two types of photovoltaic devices do not show significant difference (Figure 7). 


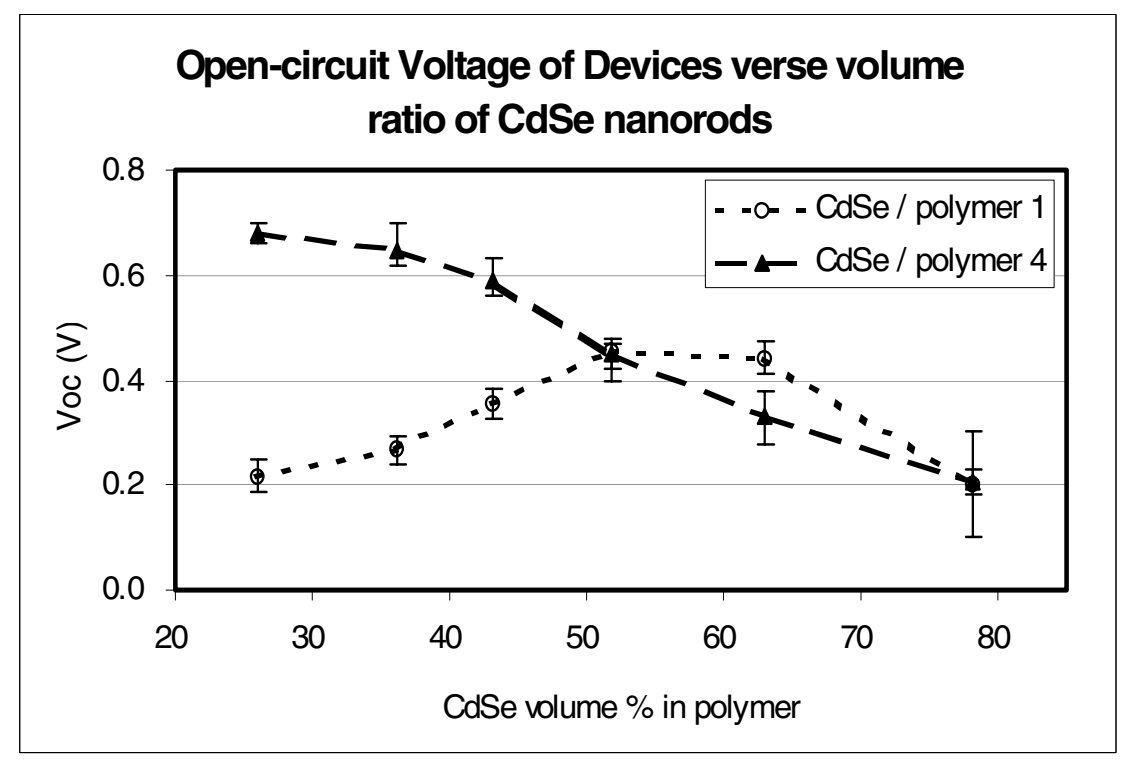

Figure 5. Open-circuit voltage of photovoltaic devices made using polymer 1 (dot line) and polymer 4 (dash line) as function of nanorod volume ratio.

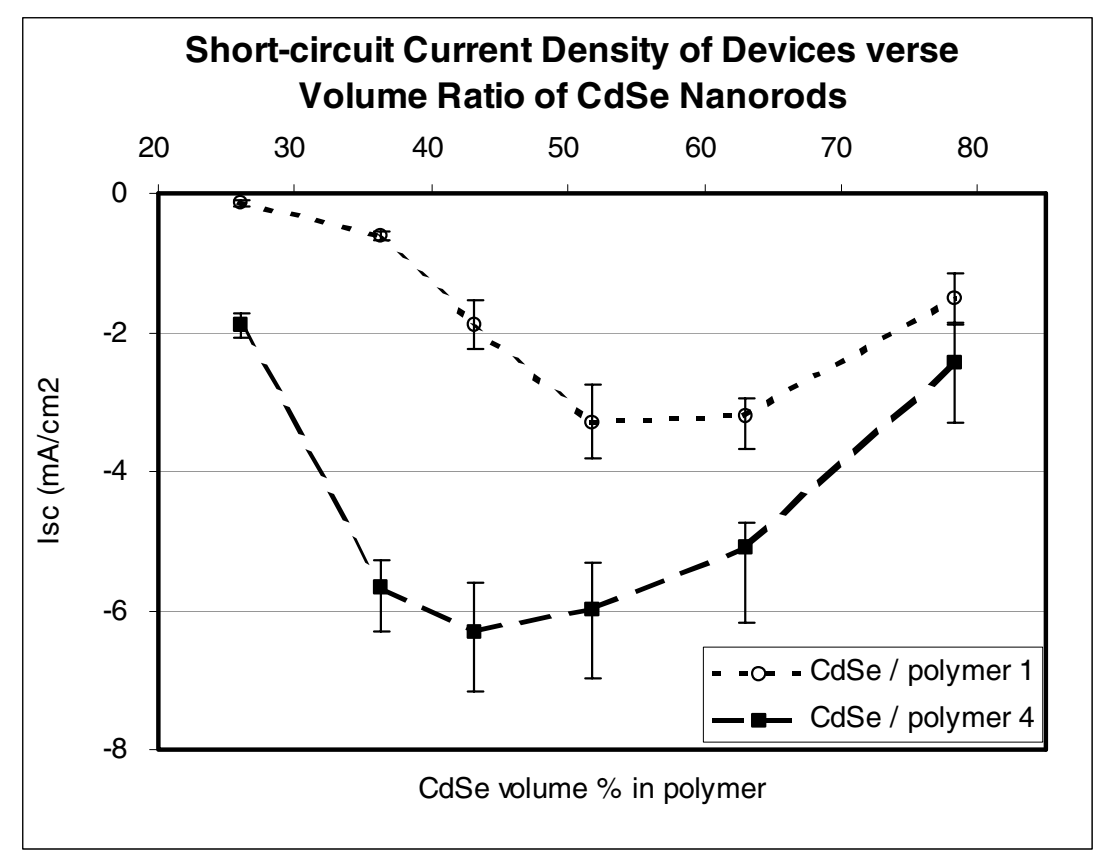

Figure 6. Open-circuit voltage of photovoltaic devices made using polymer 1 (dot line) and polymer 4 (dash line) as function of nanorod volume ratio. 


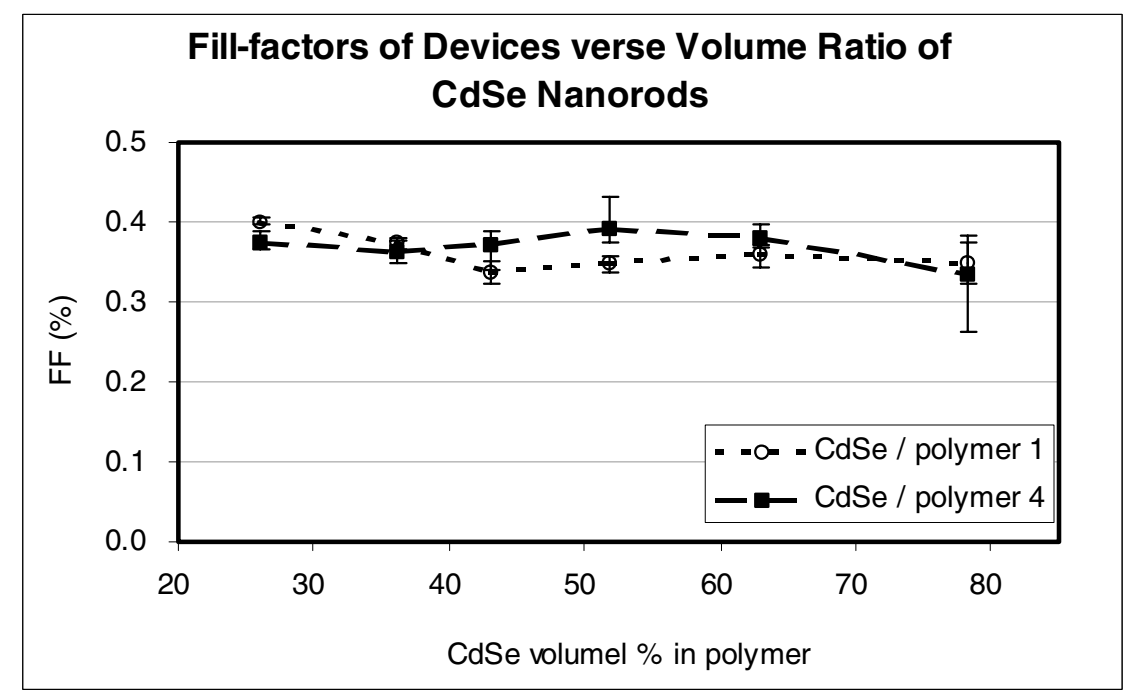

Figure 7. Fill-factors of photovoltaic devices made using polymer 1 (dot line) and polymer 4 (dash line) as function of nanorod volume ratio

Figure 8 shows a example of current density-voltage curves of two devices made using polymer 1 and polymer $\mathbf{4}$, respectively.

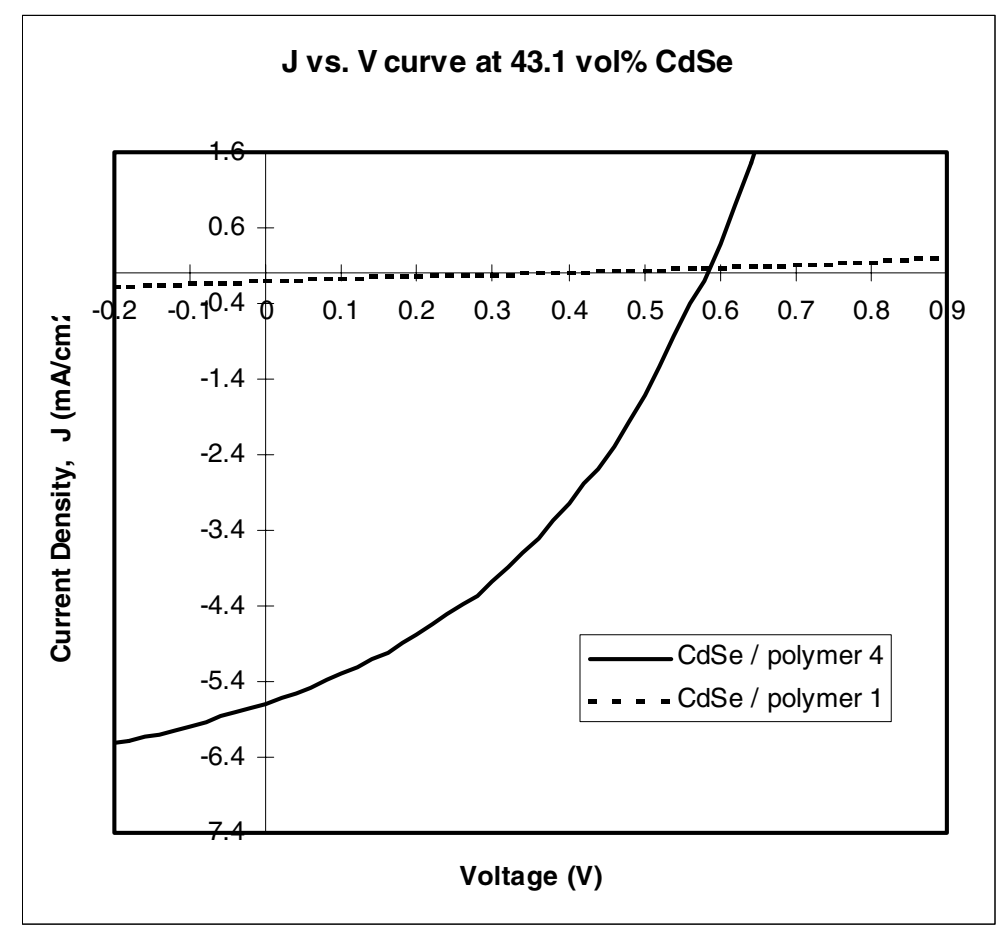

Figure 8. Current-voltage curves of devices made using polymer 1 (dot line) and polymer 4 (solid line) with $43.1 \%$ of $\mathrm{CdSe}$ volume ratio. 